\title{
Violent conjunctures in democratic India
}

\section{Sten Widmalm}

To cite this article: Sten Widmalm (2018) Violent conjunctures in democratic India,

Commonwealth \& Comparative Politics, 56:2, 257-259, DOI: 10.1080/14662043.2018.1435160

To link to this article: https://doi.org/10.1080/14662043.2018.1435160

\section{Published online: 11 Mar 2018.}

Submit your article to this journal

\section{Article views: 112}

Q View related articles $\sqsubset$

View Crossmark data $[\pi$ 


\section{BOOK REVIEWS}

Violent conjunctures in democratic India, by Amrita Basu, Cambridge, Cambridge University Press, 2015, xxviii + 334 pp., £23 (paperback), ISBN 978-1107461321

Where is India's democracy heading? There is much to indicate that India is going in the wrong direction, as seen in the murders of secular activists, and of journalists such as Gauri Lankesh; in the attacks on minorities carried out by groups euphemistically labelled 'gau rakshaks' (cow vigilantes); in the government's cut-off of supply lines for 20,000 NGOs and in the significant reduction in the space available for the free expression of opinions. Those who seek to defend basic democratic principles - especially the idea of secularism - face a pincer movement. From above they must contend with the central government under Prime Minister Narendra Modi and with state governments led by his Hindu nationalist Bharatiya Janata Party. From below they are attacked by actors in civil society, including disciplined cadre organisations, ad hoc criminal gangs, fanatical religious leaders (often with a strong penchant for yoga exercises) and a business community that feels entitled to act above the law as long as so doing might be thought to contribute to the country's economic growth. These varied elements combine to form a Hindu Rashtra - an ethnic Hindu state or nation - on the ashes of the civil liberties, secular ideals and values of political tolerance which India long pursued after independence.

However, this portrayal of current developments in India is often dismissed as 'alarmist' and heavily biased. It is thought exaggerated, amongst other things because the country's democratic performance has always fluctuated. Indeed, India's history over the last 70 years has been marked by 'unrest', rioting and political violence throughout. Recall, for instance, the 'pause' in Indian democracy during Indira Gandhi's Emergency from 1975 to 1977. Or consider the violence in Punjab and Kashmir, which peaked under Congress (I) governments. And yet, Indian democracy has defied every forecast of its doom.

Such a corrective is important. It puts tragic episodes into perspective and without necessarily downplaying their importance. It urges us to take a step back, to get some distance from the 'alarmists' and to make a more balanced analysis of what is happening. In this context, Amrita Basu's most recent contribution, Violent conjunctures in democratic India, is very timely. Basu takes a longterm perspective on the campaigns, strategies and policies pursued by the BJP now in power in India, as well as by its various support groups (which we commonly classify as social movements).

Basu's objective is to identify the conditions under which Hindu nationalists act against minorities, and when and why their actions may become violent. She therefore analyses the BJP's behaviour over nearly three decades in four states: Gujarat, Uttar Pradesh, Rajasthan and Himachal Pradesh (her treatment of the four states is 
somewhat uneven, however). She examines the four cases against the background of a more general description of how various governments in India have at times conducted consensus-based policies, and at others promoted different religious or ethnic identities. She describes how the Jan Sangh (subsequently the BJP) has sought to alter the educational and judicial systems, and to shape the character of India's political culture. She shows too how, in so doing, it has often enlisted the support of ideological think tanks and cadre organisations such as the Rashtriya Swayamsevak Sangh (RSS) or the Vishwa Hindu Parishad (VHP), or of other social movements or civil society actors which are members of the Sangh Parivar. In building her argument, Basu avoids the common mistake of considering only how political parties act, or how NGOs and civil society actors behave. It is the effect of their interaction, rather, which stands at centre in her analysis.

Her relentless and detailed treatment displays deep insight into political processes in India bearing on the treatment of minorities by the majority. Taking us back in time, she systematically revisits traumatic events over the last three decades (when the Hindutva movement has grown and become strong) in which minorities and the politically weak have suffered badly.

What Basu does, essentially, is to describe some important components in the process commonly known as autocratization. This is when democracies, slowly and incrementally, are dismantled and replaced by authoritarian rule at all levels of power from the bottom to the top. There is reason to worry that Indian democracy may go out with a whimper. What holds such a process back, mainly, is the misalignment often seen in terms of political composition between the national government, a given state government and various actors in civil society. When these elements do align, they can create what Basu calls a perfect storm. The massacre of Muslims in Gujarat in 2002 was such a storm.

Basu's observations apply as well, unfortunately, to many cases outside India where populism is rife and political tolerance on the wane. In India, the Hindu right has used violence and made systematic changes in law and policy in order to undermine secularism, restrict freedom of expression and promote a nationalist narrative of the country's history. These moves have been deliberate and planned. If Basu's analysis is correct, then the recent election results in Gujarat are an indication of more violence to come.

Violent conjunctures in democratic India is not without weaknesses. The discourse on ethnic violence in India reviewed by the author is mainly represented by a handful of scholars based in the United States. There are more scholars, besides Basu, who have been analysing the connection between party politics and social movements. Some have even focused on India. References are also lacking to important studies of the 'saffronization' of the curriculum of Indian schools. She emphasises, moreover, the need to 'recognise the potentially undemocratic qualities of civil society'; in view of this, she ought to have cited the work of many of those who have done just that. William Shirer and Sheri Berman, two famous examples, have done so with regard to the Weimar republic (the former in 1960, the latter in 1997).

Such weaknesses are far outweighed, however, by the strengths of the book in analysing the country's political development over long periods and in exposing the problems which pose a particular challenge to India's democracy. Basu 
provides a thorough analysis of what happens in India when political forces align at several levels and (intentionally) do what they can to undermine democracy. The central government of India opposes civil liberties organisations in a manner which Pakistan and Nepal have lately decided to follow - not the other way around. The vacuum left behind is being filled by civil society actors with an autocratic mindset. Unfortunately, the points bravely and thoroughly made by Amrita Basu will not calm down the so-called alarmists.

Sten Widmalm

Uppsala University

sten.widmalm@statsvet.uu.se

(c) 2018 Sten Widmalm https://doi.org/10.1080/14662043.2018.1435160

Check for updates

\section{Democratic dynasties: state, party and family in contemporary Indian} politics, edited by Kanchan Chandra, New York, NY, Cambridge University Press, 2016, xxii + 279 pp., $£ 19.99$ (paperback), ISBN 9781107558915

As the title suggests, this edited volume undertakes a study of a modern anomaly - the presence of dynastic politics in a democratic political system. The persistence of dynastic politics and its evaluation is the central concern of the book, a task which it undertakes through an examination of a dataset prepared by Chandra, Bohlken and Chauchard - all contributors to the book. The dataset profiles the members elected in the last three Lok Sabha elections (2004, 2009 and 2014). This data on the dynastic linkages of MPs from three successive Parliaments has been linked to other types of available data (such as census block level data, GIS maps, and previous work on measurement of party organisations) to chart the form and spread of dynastic linkages in modern Indian politics. This task is commendable, as relevant quantitative data on Indian politics has been difficult to gather in a systematic fashion, especially as few generalisable datasets exist in this format.

This dataset is the centre piece of the project reported in this volume, which tests a set of related hypotheses in successive chapters, analysing the propensity of 'dynasticism' to appear in connection with weakly organised and autocratically run parties or parties dominated by forward caste factions (chapters 4 and 7), in backward, rural constituencies as compared to urban, and more literate constituencies (chapter 3), and other related criterion such as gender, caste and political experience as it relates to 'dynasticism' (chapters 5, 6 and 8). The binding argument of the book is that certain operative aspects of the Indian political system are the generative principle behind the emergence of these dynasties, and that they are a 'systematic product of modern democratic institutions: state and party' (p. 5) rather than remnants of the past, or traits hardly uniquely 'Indian' in their manifestation. The authors insist that the presence of culture does not 